\title{
Comentário ao trabalho de Sandra Schaffa Desconcerto na clínica: erotismo na transferência e na contratransferência ${ }^{l}$
}

\author{
José Martins Canelas Neto $^{2}$
}

Meu objetivo nesse texto, que não é um artigo sobre o tema, é de, a partir de alguns pontos trazidos por Sandra Schaffa em seu trabalho, levantar algumas questões quanto à técnica e à visão metapsicológica sobre o amor de transferência (Übertragungsliebe), neologismo criado por Freud.

Inicialmente gostaria de examinar a tradução do termo alemão. Amor de transferência ou transferência amorosa? Trata-se da descrição do que inicialmente foi considerado um obstáculo ao processo analítico. Sandra desenvolveu muito bem este ponto. A palavra amor abre para inúmeras acepções em psicanálise e é um sentimento quase sempre presente na vida normal dos seres humanos. No Dicionário Freudiano de Le Guen e Bourdieu, é definido assim: "uma modalidade de colocação em ação das pulsões sexuais que supõe um investimento libidinal do objeto total, se distinguindo assim das pulsões parciais." (p.79) Nesse sentido entendemos o amor nas relações entre os seres humanos em geral, as relações amorosas. Quando esse sentimento aparece durante o processo analítico, ele adquire características próprias, uma vez que constitui a transferência. Por isso, prefiro falar em amor de transferência ao invés de transferência amorosa. Isto é, trata-se para mim de um tipo particular de sentimento amoroso que emerge no enquadre analítico por meio da transferência.

Se tomarmos o caso de Maria, por exemplo, Sandra descreve "uma exigência impetuosa de amor no encontro analítico". Essa exigência aparece no texto de Sandra várias vezes

\footnotetext{
${ }^{1}$ Este trabalho foi apresentado na mesa "Desconcertos em análise : o erotismo na trasnferência e na contratransferencia” com Sandra Lorenzon Schaffa no I Simpósio Bienal "O mesmo, o outro: Psicanálise em movimento" da Sociedade Brasileira de Psicanálise de São Paulo.

2 Analista didata da Sociedade Brasileira de Psicanálise de São Paulo.
} 
como "exigência de presença". O aspecto de exigência impetuosa da demanda de amor da paciente faz pensar na pulsão, descrita por Freud também como exigência de trabalho do somático imposto ao psíquico. O caráter passional desse amor de transferência fica evidente na descrição do caso. Sandra coloca a importante questão técnica: como lidamos com essa exigência durante a análise?

Uma primeira dificuldade seria: o analista se deixaria seduzir? Ou teria uma atitude de censura e rejeição? $O$ amor de transferência não é uma forma patológica de transferência, o que o caracteriza é o fato de ser um amor que tem a particularidade desconcertante de aparecer durante uma análise. Por que desconcertante? Por razões morais, profissionais, culturais, etc. Será o analista que fará um mau uso da transferência se ele ceder à sedução.

Do lado do analista, assim como no teatro, nada pode acontecer de real. Por outro lado, para o paciente há a conviç̧ão de que realmente acontece o amor pelo analista. Octave Mannoni num artigo intitulado - $O$ amor de transferência e o real - coloca a ideia de um abismo estrutural fundamental nessa situação: “o analista do lado do imaginário e o paciente do lado do real e os dois têm razão.” (p.10). O autor admite que seria ilusório e impraticável distinguir o amor de transferência de um verdadeiro amor. Conhecemos a relação estreita entre amor e loucura.

O amor de transferência questiona inevitavelmente a metapsicologia. A técnica, ou a prática analítica se preferirmos, vem antes da teoria. Dessa maneira o amor de transferência também coloca sérias questões à metapsicologia freudiana.

O amor de transferência, não há dúvida, traz um obstáculo importante à análise e pode fazê-la fracassar. Coloca uma questão crucial sobre o fazer analítico nessa situação. Impõe ao analista uma técnica justa e difícil. $\mathrm{O}$ analista tem que evitar se colocar como senhor do real de alguma coisa, pois seu único terreno de domínio situa-se no imaginário. 
Na transferência há sempre uma obscuridade. É a obscuridade do real. Podemos supor que isso tem a ver com a compulsão de repetição e a pulsão de morte. A repetição transferencial, nesse sentido, não é somente imaginária, ela também depende de uma lógica da pulsão de morte. O real, dizia Lacan, é "o que retorna a seu lugar". Essa obscuridade da transferência também caracteriza o objeto do desejo; esse obscuro objeto do desejo.

Voltando ao caso de Maria, seu amor se caracterizava, como mostrou Sandra, pela questão central da necessidade da presença da analista. Creio que Sandra se referiu à presença real dela junto à paciente.

Essa necessidade de presença deu, a meu ver, o colorido, ao amor de transferência de Maria. E foi em torno dela que se desenrolou o eixo central da análise, como nos contou Sandra. A vivência do amor de transferência da paciente mostrou-se totalmente impregnada pela necessidade de presença, talvez de contato táctil também, não sei.

Sandra levantou a hipótese de uma falha na constituição do materno. Eu acrescentaria materno primário. Este comportando provavelmente a existência de aspectos da constituição psíquica da paciente que envolvem ruídos traumáticos nunca elaborados. Estou totalmente de acordo com a reflexão de Sandra sobre a falha na ação específica, a experiência de ruptura de continuidade do materno que leva ao temor permanente do desmoronamento (Winnicott). Estamos no terreno da estruturação narcísica primária do sujeito.

Diante do contexto dessa análise, Sandra nos mostrou que antes de mais nada era preciso sustentar a ambiguidade básica que evoquei acima entre imaginário do analista e real da paciente no interior da demanda narcísica de amor fortemente sexualizada. Sandra também coloca algo importante do ponto de vista da condução do tratamento, a 
necessidade de uma permanente modulação libidinal da presença da analista. É necessário que o analista não esqueça e fique sempre atento a como está sendo a qualidade de sua presença libidinal na sessão.

Sandra coloca a questão da justa distância entre corpos do analista e da paciente. O analista tem que se ancorar à palavra, para permanecer na posição analítica. Mas como isso é possível em tamanha explosão passional? Um ponto que para mim é norteador é a ideia de Freud de terreno de jogo da transferência. Essa expressão aparece no caso do Homem dos ratos, mas a ideia é anterior e remonta a uma discussão na Sociedade Vienense, em 1907, citada por Octave Manoni, quando Freud explica o fato de existirem pacientes perversos que nunca passam ao ato, explicando que: "é preciso que haja suspensão da realidade, como no teatro". Nesse sentido, o espaço analítico torna-se o terreno de jogo da transferência tendo o estatuto da fala como seu pilar central. Foi Winnicott que mais desenvolveu essa ideia de Freud, com as noções de espaço transicional e potencial e de objetos transicionais.

Sandra coloca a ideia de um duplo imaginário protético que ela teve que assumir. Isso me parece muito próximo dessa ideia de terreno de jogo da transferência. A situação exigiu um certo grau de presença no real da paciente.

Num trabalho meu sobre o vazio, relato o caso de uma paciente para o qual um amor de transferência apareceu. Porém, com outro colorido, muito diferente do de Maria. Minha paciente havia se curado recentemente de um câncer e chegou à análise bastante deprimida. Não havia a pregnância da necessidade de presença do analista como no caso de Maria. Foi possível manter um terreno de jogo libidinal que permitiu o processo se desenrolar e chegarmos, entre outros aspectos, a questões edípicas, sobretudo com a figura paterna. Estávamos mais no terreno da neurose, embora o traumático não estivesse ausente. Penso que com Maria estaríamos talvez no terreno que chamo de nãoneurose, no caso provavelmente de uma falha narcísica central. 
Então podemos talvez falar em diferentes modos de amor de transferência. Diferentes coloridos desse amor. Acho que na vida também é assim, não é?.

Mas, na análise, a principal dificuldade é então: se o amor é real, como analisá-lo, isto é, ficar no imaginário? Sandra cita Fédida, que diz que o valor de crise da contratransferência é o de sinalizar o lugar de emergência do traumático da sexualidade. No caso de Maria, esse traumático se revela na constituição mesma do narcisismo primário. A justa distância entre os corpos também pode ser ligada à ideia do abismo entre real do amor e imaginário do analista. Parece ser necessário que o analista não misture esses planos durante a análise.

Por fim, é interessante notar como os sonhos da paciente figuram a intensidade das pulsões ameaçadoras (campos gelados e incêndios). Nessa intensa e passional aventura amorosa, Maria viveu nessa análise, como mostrou Sandra, um amor de transferência que serviu de pilar restaurador de seu narcisismo primário. Esse processo só foi possível porque sua analista não foi sugada pelo real da paciente, sabendo manter a justa distância, usando sua criatividade e recursos imaginários, assim como o investimento da palavra como único meio do processo analítico poder se desenrolar.

Cito, finalizando, a sábia conclusão da Sandra: “o caminho do analista é outro para o qual a vida real não oferece modelo, mas decorre de uma disparidade irredutível entre os sujeitos, tempos e cenas psíquicas a que o diálogo analítico dá vida." Gostei bastante, Sandra, de sua concepção da análise como disparidade subjetiva, ou também disparidade entre subjetividades, tempos e culturas. Essa ideia me pareceu fecunda por evitar a noção de assimetria que me parece ter um viés hierárquico: o analista como o que sabe, o senhor do real e o analisando que atua suas neuroses.

O que é sempre duro quando nos deparamos com a transferência e a contratransferência é sua estranheza, sua aparente obscuridade e mistério. E para isso a experiência, a idade, os anos rodados de clínica não servem de nada. A cada novo paciente, novas 
disparidades subjetivas aparecem. Novos sofrimentos e emoções, mas sempre com a qualidade do novo, o que torna nossa profissão atraente e nada monótona, sempre com mudanças, mesmo que aos trancos e barrancos!

\section{Referências}

Le Guen, C. - Dictionnaire Freudien. Paris, P.U.F., 2008

Manoni, O. L'amour de transfert et le réel. In Études Freudiennes, Nos. 19-20, Maio de 1982. Paris, Evel, 1982. 